\title{
Innovations that changed Mammalogy: the Japanese mist net
}

\author{
Hugh H. Genoways, Suzanne B. McLaren, and Robert M. Timm* \\ University of Nebraska State Museum, University of Nebraska-Lincoln, Lincoln, NE 68588, USA (HHG) \\ Section of Mammals, Edward O'Neil Research Center, Carnegie, Museum of Natural History, Pittsburgh, PA 15206, USA (SBM) \\ Department of Ecology \& Evolutionary Biology and Biodiversity Institute, University of Kansas, Lawrence, KS 66045, USA \\ $(R M T)$
}

*Correspondent: btimm@ku.edu

Our second selection for an innovation that changed mammalogy is the Japanese mist net, which was a repurposing of a centuries old invention. Prior to the availability of these nets, mammalogists had limited ability to sample members of the order Chiroptera. Samples of bats were obtained primarily from day roosts or hibernacula, or by shooting them in the evening twilight as they hawked insects. Tropical species were particularly underestimated by the old methods. The use of mist nets by both American mammalogists and ornithologists began in the 1950s, resulting in an explosion of research and publications about bats and birds in all areas of their biology. The capability to capture volant animals alive and unharmed has contributed significantly to our understanding of the Chiroptera, which is second only to the order Rodentia within Mammalia in species diversity, with more than 1,400 recent species described and more being discovered as our knowledge continues to expand.

Originally constructed of silk dyed black, the Japanese style of mist net-kasumi-ami-is believed to have been developed in the middle of the 17th century in Ishikawa Prefecture along the coast of the Sea of Japan (Fig. 1). From there, it spread to the nearby prefectures of Gifu and Nagano, and beyond. These prefectures were at the point of landfall along a major flyway for birds, especially thrushes, bramblings, siskins, buntings, and sparrows, migrating from summer breeding grounds in northeastern Asia and Siberia to winter in southern Japan. The nets were used for catching small birds both for local consumption and sale of the meat. The Japanese attempted to control these practices with a series of conservation laws beginning as early as 1873 , but these laws only were weakly enforced (Macpherson 1897; Austin 1947; Aldous 2015).

The use of mist nets by the Japanese to catch birds first was made known to scientists in North America through a report written by Oliver Austin (1947) during the Allied Occupation of Japan. Austin, a Harvard-educated ornithologist, served as Head of the Wildlife Branch, Natural Resources Section,
General Headquarters, Supreme Commander for the Allied Powers, from its inception in September 1946 until the successful completion of its mission in February 1950. Austin's main objective was the conservation of Japanese wildlife, restoration of sound wildlife management practices, and the prevention of overexploitation of these resources by the U.S. military personnel and Japanese netters. Summarizing this harvest, Austin (1947:13) wrote "the yearly take . . . averaged 4,500,000 birds . . . this adds an appreciable amount of protein food to the diet . . . along the flight routes." Austin's information on the efficient use of mist nets in capturing birds was picked up and put to use by ornithologists in North America, who recognized the potential of these nets for their work (McClure 1956a, 1956b; Low 1957; Keyes and Grue 1982).

In 1950, Walter Dalquest received three silk mist nets from his mentor George Lowery, the ornithologist-mammalogist at Louisiana State University, to use for his dissertation work on the mammals of San Luis Potosí. His work was met with almost immediate success, catching species of bats unknown to the region and catching rare species in series not seen previously; but there also was considerable trial and error. One evening a cow ran through an open net catching the net on its horns and dragging it into the surrounding brush. On another evening, nets probably were opened too early and were damaged by capturing several large birds, including a Black Vulture, a Common Pauraque, two Plain Chachalacas, and three Whitetipped Doves. Based on his initial experience netting bats in San Luis Potosí, Dalquest (1954) had some observations for future bat netters: 1 ) netting does not give a complete picture of the bat fauna of an area, 2) placement of nets must be adapted to local conditions, 3 ) nets should be set close to the ground, 4) nets should be guarded when set or visited at short intervals, 5) trapped bats should be removed from the net immediately, and 6) be prepared to take careful notes on times bats are captured and other natural history observations. By 1957, W. B.

(C) The Author(s) 2020. Published by Oxford University Press on behalf of the American Society of Mammalogists, www.mammalogy.org. 
Davis of College Station, Texas, was advertising "Japanese 'mist' bat nets" for sale in the Journal of Mammalogy (38:425, August 1957).

Although the original mist nets were constructed of silk for smaller birds and cotton for waterfowl, modern nets are most commonly made of nylon or polyester. Mesh is the size of the small openings in the net, with nets of varying mesh being available depending upon the general sizes of the bats to be captured. The trammels are the cording that run horizontally through the net below the top to create shelves. The shelves are the baggy part of the net between the trammels where most of the bats will be captured. Most modern nets have four shelves and come in standard lengths of 2.6, 6, 9, 12, and $18 \mathrm{~m}$. Some specialty nets can be as large as $6 \mathrm{~m}$ in height and $30 \mathrm{~m}$ long.

The placement and arrangement of nets to capture bats will vary with terrain, habitat, and experience, and is in many cases more art than science, along with the ability to see the area as the bats do (Kunz and Kurta 1988). In arid areas, setting the nets close to the ground or near water is a good strategy because bats typically emerge from day roosts and fly low to drink. In tropical areas, bats often use flyways through the forest or fly higher than the average net height, and a specialized strategy is to stack nets one above another on a rig and pulley system to create what is known as a canopy or heaven net (Handley 1967; Humphrey et al. 1968). Using this method, the nets can be raised and lowered to permit removal of captured bats, while sampling much higher in the air or forest than could be done with only ground-level nets.

A popular alternative to mist nets is the harp trap, first designed by Dennis Constantine when he needed to catch large numbers of Tadarida brasiliensis exiting Carlsbad Caverns (Constantine 1958). The modern version of the harp trap uses two or more banks of vertically strung, monofilament fishing line (testing 2.7-3.6 kg) spaced apart by $2.5 \mathrm{~cm}$ (Kunz and Kurta 1988). "The trap is designed so that bats encountering the first bank of lines will either fall directly into a collecting bag, or pass through the first bank and become trapped in the space between the two banks and fall into the collecting bag" (Berry et al. 2004:335-336). There has been much discussion comparing mist nets and harp traps, but harp traps seem to work best in confined spaces where high numbers of bats can be expected such as cave entrances, buildings exits, narrow ravines, and similar sites (Francis 1989).

Recent innovations in monitoring bat diversity include the use of acoustic techniques and even radar. Although mist nets have provided an exciting ability to sample bats, as early as Dalquest's work it was known that not all species of bats are well-surveyed only by using mist nets (Dalquest 1954). Larsen et al. (2007) reviewed many of the biases and assessed the efficiency of mists nets, documenting that the average capture rate of bats passing a mist net set in a flyway was only $3.2 \%$. Some species vary in their ability to detect and avoid mist nets, other species may fly too high to contact any net, and rare species may be flying somewhere that mammalogists do not think to place their nets. Acoustic techniques have the advantage of being able to sample for longer times; not having

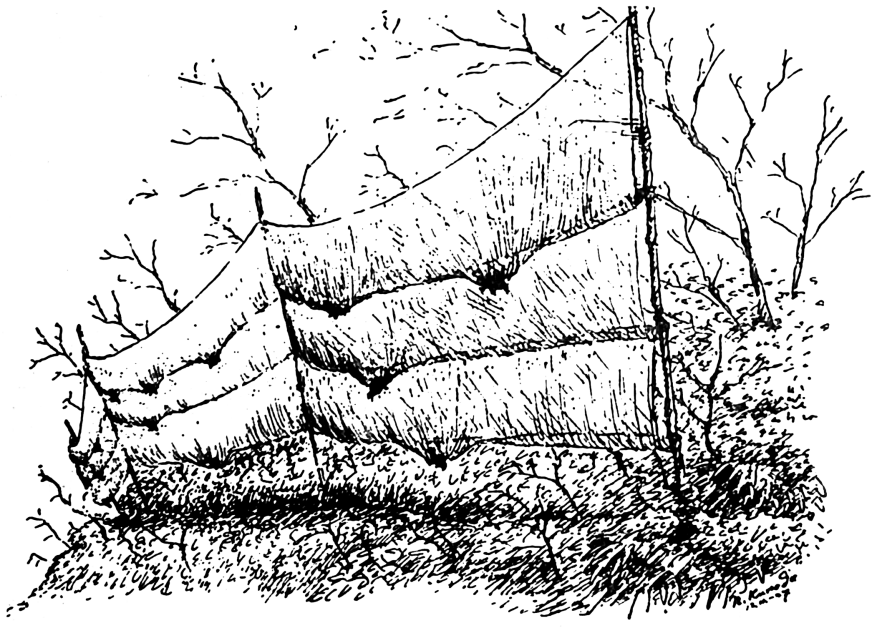

Fig. 1.-A traditional silk, three-shelf mist net used to capture birds in Japan, perhaps since the mid-1600s. Nagahisa Kuroda, Japanese ornithologist and artist (birth: 1916, death: 2009), made this and other paintings from nature in 1947 while he was working with Oliver Austin in the Wildlife Branch for the Allied Powers (Austin 1948; Austin and Kuroda 1953). He was an honorary member of the American Ornithological Union and wrote extensively on birds, illustrating many of his publications. His father, Nagamichi Kuroda, was a charter member and was elected an Honorary Member of the ASM in 1959. Reprinted from Austin (1947).

to monitor nets constantly, more sites can be monitored simultaneously, greater areas can be sampled, and fewer bats fly by without being detected. Many recent studies include a combination of two or more techniques to assess bat diversity. However, when it is necessary to actually handle bats, the mist net often is the best option. Despite some drawbacks of the Japanese style mist net, this innovation has substantially facilitated our understanding of this highly diverse order of mammals, and is still one of the most effective ways to capture bats unharmed.

\section{ACKNOWLEDGMENTS}

In Japan, Collections Director Miyako Tsurumi, Yamashina Institute for Ornithology, provided critical insights into the history of the painting to read used herein as Figure 1. At the University of Kansas, B. L. Clauson, K. Severud Cook, S. D. Fowler, M. Ito, and J. A. Johnson generously shared their expertise on Japanese art with us, considerably improving our understanding of Kuroda's illustration. E. J. Heske and L. A. Ruedas critically reviewed an earlier draft of this manuscript. M. G. Girard's masterful efforts in improving the figure used herein are most appreciated.

\section{Literature Cited}

Aldous, C. 2015. A tale of two occupations: hunting wildlife in Occupied Japan, 1945-1952. Journal of American-East Asian Relations 22:120-146.

Austin, O. L., JR. 1947. Mist netting for birds in Japan. General Headquarters, Supreme Commander for the Allied Powers, Natural Resources Section Report, Tokyo 88:1-24. 
Austin, O. L., JR. 1948. Japanese ornithology and mammalogy during World War II (an annotated bibliography). General Headquarters, Supreme Commander for the Allied Powers, Natural Resources Section Report, Tokyo 102:1-45.

Austin, O. L., JR., AND N. Kuroda. 1953. The birds of Japan: their status and distribution [foreword]. Bulletin Museum of Comparative Zoology 109:282-285.

Berry, N., W. O'Connor, M. W. Holderied, and G. Jones. 2004. Detection and avoidance of harp traps by echolocating bats. Acta Chiropterologica 6:335-346.

Constantine, D. G. 1958. An automatic bat-collecting device. Journal of Wildlife Management 22:17-22.

Dalquest, W. W. 1954. Netting bats in tropical Mexico. Transactions of Kansas Academy of Science 57:1-10.

FrancIS, C. M. 1989. A comparison of mist nets and two designs of harp traps for capturing bats. Journal of Mammalogy 70:865-870.

Handley, C. O., JR. 1967. Bats of the canopy of an Amazonian forest. Atas do Simpósio sôbre a Biota Amazônica 5:211-215.

Humphrey, P. S., D. Bridge, And T. E. Lovejoy. 1968. A technique for mist-netting in the forest canopy. Bird-Banding 39:43-50.
Keyes, B. R., AND C. E. GRue. 1982. Capturing birds with mist nets: a review. North American Bird Bander 7:1-14.

Kunz, T. H., AND A. Kurta. 1988. Capture methods and holding devices. Pp. 1-29 in Ecological and behavioral methods for the study of bats (T. H. Kunz, ed.). Smithsonian Institution Press. Washington, D.C.

Larsen, R. J., K. A. Boegler, H. H. Genoways, W. P. Masefield, R. A. Kirsch, And S. C. Pedersen. 2007. Mist netting bias, species accumulation curves, and the rediscovery of two bats on Montserrat (Lesser Antilles). Acta Chiropterologica 9:423-435.

Low, S. H. 1957. Banding with mist nets. Bird-Banding 28:115-128. Macpherson, H. A. 1897. A history of fowling. David Douglas. Edinburgh, Scotland.

MCClure, H. E. 1956a. Methods of bird netting in Japan applicable to wildlife management problems. Bird-Banding 27:67-73.

McClure, H. E. 1956b. Protecting grain fields in Japan from pilferage by birds. Journal of Wildlife Management 20:462-464.

Submitted 6 February 2020. Accepted 22 February 2020.

Associate Editor was Luis A. Ruedas. 